\title{
Teaching community of practice: permanent training strategy for teaching vocational training in nursing*
}

\author{
Comunidade de prática docente: estratégia de formação permanente para a docência \\ na educação técnica em enfermagem \\ Comunidad de práctica docente: una estrategia de formación continua para la docencia \\ en la formación técnica en enfermería
}

How to cite this article:

Ribeiro-Barbosa JC, Silva GTR, Backes VMS, Silva RMO, Oliveira MLC, Fernandes JD. Teaching community of practice: permanent training strategy for teaching vocational training in nursing. Rev Esc Enferm USP. 2021;55:e20210238. https://doi.org/10.1590/1980-220X-REEUSP-2021-0238.

Juliana Costa Ribeiro-Barbosa ${ }^{1}$

D Gilberto Tadeu Reis da Silva ${ }^{1}$

iD Vânia Marli Schubert Backes²

(iD) Rosana Maria de Oliveira Silva ${ }^{1}$

(iD) Maria Luiza Carvalho de Oliveira ${ }^{3}$

(iD) Josicelia Dumêt Fernandes ${ }^{1}$

* Extracted from the thesis: "Formação para a docência em enfermagem nas Escolas Técnicas do SUS: possibilidades em Comunidade de

Prática”, Universidade Federal da Bahia, 2021

${ }^{1}$ Universidade Federal da Bahia, Escola de Enfermagem, Programa de Pós-Graduação em Enfermagem, Salvador, BA, Brazil.

${ }^{2}$ Universidade Federal de Santa Catarina,

Programa de Pós-Graduação em Enfermagem, Florianópolis, SC, Brazil.

${ }^{3}$ Universidade do Estado do Amazonas, Escola

Superior de Ciências da Saúde, Manaus, AM, Brazil.

\section{ABSTRACT}

Objective: To identify possibilities for developing teaching community of practice as a permanent training strategy for teaching in vocational nursing education. Method: This is a qualitative action research, carried out with vocational training professors and pedagogical coordination of a Unified Health System Vocational School of Ceará. Data were collected by focus groups and submitted to Bardin's content analysis, supported by the Qualitative Data Analysis Software. Results: Possibilities for the development of teaching community of practice were identified by the perception of the need for teacher training, difficulty in reconciling work and study, and the feasibility of promoting this training in a group. Conclusion: Teaching community of practice, in addition to being a viable strategy for nursing professor education, is urgent, as the training of secondary-level workers is crucial for quality of care and consolidation of the Unified Health System.

\section{DESCRIPTORS}

Faculty, Nursing; Teacher training; Education, Nursing, Associate; Nursing; Unified Health System. 


\section{INTRODUCTION}

A professor's work demands preparation and knowledge that goes beyond the specifics of a given area of knowledge so that their training needs to be consistent with the demands and complexities of being/doing a professor ${ }^{(1,2)}$. It is emphasized that teaching is a profession, therefore, it requires the acquisition of diverse knowledge and training directed to its exercise, as indicated by the knowledge base for teaching theoretical framework ${ }^{(2)}$, by presenting at least seven categories of knowledge needed by the professor for their work: general pedagogical, content, students, curriculum, pedagogical content, educational contexts and the purposes, purposes and values of education. Furthermore, teacher training interferes in student training, which makes professors' training path and their performance highly relevant to the quality of teaching-learning.

Specifically in the High School Vocational Training (EPTNM - Educação Profissional Técnica de Nivel Médio) in nursing, reflecting on professor education is also thinking about the training of nursing technicians, workers who occupy a central space in nursing/health care in the Unified Health System (SUS - Sistema Único de Saúde), due to the high number and magnitude of their attributions ${ }^{(3-5)}$. In this context, it is appropriate to emphasize the relevance of the space occupied by the SUS Vocational Schools (ETSUS - Escolas Técnicas do Sistema Único de Saúde), due to the firm commitment to base their training processes on the principles of the Brazilian health system ${ }^{(5,6)}$. It is understood, therefore, that training for teaching represents an extremely valuable topic, considering the urgent need to train workers committed to health care in and for SUS.

Still, most of the professors who work at an EPTNM in nursing are nurses, who, predominantly, do not have specific qualifications for teaching ${ }^{(7,8)}$. For these reasons, the theme of training for teaching becomes even more significant and pertinent, with a view to a qualified teaching performance that enhances critical, reflective and transformative training processes.

In this scenario, communities of practice emerge as a privileged place for learning, as they offer their members the possibility of interacting, exchanging experiences, negotiating meanings and exploring new knowledge in favor of acquisition and construction of knowledge. They are conceptualized, in general, as a group of people who have a concern, problems or enthusiasm about a topic and who deepen their knowledge and mastery when they interrelate ${ }^{(9)}$. Therefore, they are made up of groups of individuals who have common ideas and plans, engaging in the search for practical actions in their favor, promoting learning and training.

Specifically as a way of permanent education for teaching, the community of practice presents itself as a fertile ground for teacher qualification, since, through sharing teaching experiences and concrete involvement in activities and actions with a view to improving teaching, it provides opportunities for the review of educational practice itself through critical reflection and analysis, in search of teaching professionalism ${ }^{(10)}$.

Moreover, due to the space-time flexibility that admits numerous formats, the development of a community of practice as a training strategy is a very feasible proposal ${ }^{9}$. In community, both in person and virtually, professors will be able to learn and develop professionally, continuously and reciprocally, in order to qualify their teaching by deepening their knowledge.

Considering the above, the objective was to identify possibilities for the development of a teaching community of practice as a strategy for permanent training for teaching in vocational nursing education.

\section{METHOD}

\section{Study Design}

This is a qualitative study, of action research type, whose theoretical framework was knowledge base for teaching ${ }^{(2)}$, and methodological framework, action research ${ }^{(11)}$.

\section{Study Setting}

The study was carried out at an ETSUS in Ceará, Brazil, in 2019, which had an ongoing class of the vocational nursing course, a characteristic considered as a criterion for inclusion of the school in the study. Brazil has 41 ETSUS; of these, only five have ongoing classes of the mentioned course, which are located in Acre, Amazonas, Ceará, Paraná and Santa Catarina. The creation of this school in 2005 represented a significant advance in the Permanent Education Policy in the municipality and surrounding region, with the mission to develop intervention strategies in vocational and health worker training ${ }^{(12)}$.

It is worth noting that this ETSUS had already been included in the first stage of the research project developed between 2018 and 2021, during the $\mathrm{PhD}$ of one of the authors, which had as locus the five aforementioned schools. Its selection is justified, because Ceara is the second state with the highest number of ETSUS (four), preceded only by São Paulo (seven), which currently does not have any school with an ongoing class of the course in focus. Furthermore, the school's ready acceptance of being the setting for action research is cited.

\section{Study Participants}

The study included 13 professors of a vocational nursing course and the pedagogical coordinator from an ETSUS in Ceará. Responding directly for the course, in the case of the coordinator, having been a teacher, being teaching or being scheduled to act as a professor in the current class of that course, for teachers, were defined as inclusion criteria. Being on leave, vacation or away from work at the time of data collection were defined as exclusion criteria. It should be noted that the approach and invitation to participants took place in September 2019 through the creation of a group in a message exchange application, with the help of the school secretariat and pedagogical and coordination of the course in question.

\section{Data Collection}

The data collection of this action research was structured according to the following organizational phases: exploratory phase; research topic; problem placement; place of theory; hypotheses; seminar; observation field; data collect; learning; formal knowledge/informal knowledge; action plan; and external disclosure $^{(11)}$. 
Considering these phases, the exploratory phase took place between January and October 2019 from the development of the first stage of the research project mentioned above, when it was possible to approach the study setting and participants, knowing some school characteristics and professors' training-professional profile, making a situational diagnosis. Also, through data published on the Ministry of Health portal regarding ETSUS and on-site observation, it was possible to further explore the field of observation, detecting some problems and potential solutions.

Training for teaching was established as the theme and main problem, and the knowledge base for teaching ${ }^{(2)}$ and the community of practice ${ }^{(9)}$, as theoretical framework and solution hypothesis, respectively. It is pointed out that the community of practice was presented to the participants through the availability of a text about it and a moment of expository and dialogued theorizing, addressing its main points. At the time, it was highlighted that communities could conform in numerous ways, including virtually.

The conducting group, seminar stage, was made up of a researcher, professors and coordinator. The field of observation was an ETSUS from Ceará, and data collection was carried out using the focus group (FG) technique. Subsequently, the phase of learning and articulation between knowledge occurred through the sharing of information, discussion of potential actions and construction of knowledge. The action plan was educational, with a view to community of practice; finally, external disclosure has taken place by publicizing the results with people and entities of interest.

Specifically, data collection used the FG as a technique, whose applicability allows extensive discussion through dialogue so that the production of data in a collective space provides opportunities for broad thematic problematization, construction of knowledge and approximation of the research with participants' reality ${ }^{(13)}$.

Six meetings were held at the school in October 2019, all previously scheduled according to participants' availability, who preferred to concentrate them in a single month and at night. Such meetings were guided by scripts with debate questions, with the first three focused more on knowing the reality of the group, its difficulties and needs related to professor education. The last three were aimed at the possibility of developing the teaching community of practice from the perspective of permanent education for teaching. Each meeting had an average duration of 1 hour and 55 minutes, totaling 11 hours and 28 minutes of data collection, and the audios were recorded, later transcribed and validated by participants. Also, field notes were made during the FG meetings, in order to record the activities developed, speeches for retake and the researcher's perceptions and reflections.

\section{Data Analysis and Treatment}

Data were subjected to thematic content analysis, which has three stages: pre-analysis - initial corpus reading and organization; material exploration - data exploration for coding and categorization; treatment of results and interpretation - identification of manifest and latent contents present in the collected material ${ }^{(14)}$. This analysis was supported by Qualitative Data Analysis Software.

\section{Ethical Aspects}

The study observed the ethical and scientific principles for research with human beings specified in Resolutions 466/2012 and 510/2016 of the Brazilian National Health Council (Conselho Nacional de Saúde), having been approved by the Institutional Review Board, under Opinion 3,556,307, in September 2019. All participants signed the Informed Consent Form and were identified with the letter $\mathrm{P}$ (participant), followed by an Arabic numeral.

\section{RESULTS}

Participants' mean age was 36 years, with an interval between 29 and 49 years, with the majority being female; $85.7 \%$ (12) had a nursing degree, and the others, in social work and systems analysis; $14 \%$ (2) of were graduates; less than half, $42.9 \%$ (6), had graduate training focused on teaching, despite the majority working in the classroom for more than six years.

From data analysis, 70 registration units (RU) emerged, organized into six subcategories and, consequently, into two categories, detailed below, which identified the possibilities for developing the teaching community of practice. It is noteworthy that such results come from the development of the FG, whose execution was made possible, in a more direct way, from the "conduction group" action-research phase.

\section{Possibilities for the Development of Teaching Community of Practice}

The possibilities for the development of teaching community of practice were identified through the subcategories below:

\section{Perception of the Need for Teacher}

Participants recognized teacher training as necessary for the exercise of teaching, since a bachelor's degree does not qualify them for this job. Having a license for teaching was identified as a way of approaching the universe of education and preparation for acting in the classroom, as it allows the acquisition of didactic-pedagogical knowledge.

(...) maybe the nurse does not have the knowledge of license for teaching, of scholars, of learning methodologies. (...) it turns to the question of bachelor's degree. (P2)

I thought of having a license just for the classroom. (P5)

(...) academic training, it prepares for a bachelor's degree and not for a license for teaching. (P6)

\section{Finding the Difficulty of ReConciling Work AND STUdY}

Participants found it difficult to work and study at the same time, due to lack of time. Thus, seeking courses for teacher qualification and taking time away from work to be in these more formal spaces of permanent training was quite difficult. In these situations, they had to choose between one or the other and, generally, work took on a priority condition.

I think I need to specialize in this and, for lack of time, I can't now. (...) rush of life, it's not working. (P3) 
(...) it is very hard for us to be able to study and work. Sometimes we have to give up our job to study. And sometimes it's not possible, because we have to work. (P5)

And when we think about the busy life that we have, we often go away to go somewhere else for that. (P10)

\section{Recognition of the Opportunity to Form a Group}

It was identified that the exchange of experiences, reflection and sharing of experiences in the group provide opportunities and contribute to the qualification of everyone involved, with a view to teaching. Participation in groups makes it viable, therefore, to form and cooperate with the formation of the other through the collective construction of knowledge.

This exchange is very important (...), there are people who already have some experience in teaching and others who do not have that much experience. (P2)

(...) the group reflect on these practices, bring experiences, some material, make it available, because you build your knowledge in terms of teaching. (P7)

(...) I think it's very important to have people committed to doing, to qualifying, to contributing to this qualification. (P10)

\section{Development of the Teaching Community of Practice}

The development of a virtual teaching community of practice was outlined from the following subcategories:

\section{Acceptance of the Teaching Community of Practice Proposal}

The Teaching community of practice proposal was accepted by participants, who qualified it as good and important for providing opportunities for the improvement of knowledge necessary for teaching.

\section{(...) the community is an opportunity to improve this knowledge} that is needed. (P7)

I thought it was a very good idea, it is possible. I hope that we reach a consensus and that we can do, build this community of practice. I liked the idea, I'm super sensitive and I want to participate. (P9)

I think it's a very important proposal, mainly taking what the professor said: "did I ever take a course focused on the pedagogical issue?". (P10)

\section{INDICATION OF TOPICS OF INTEREST FOR DISCUSSION IN THE Teaching Community of Practice}

Teaching methodologies, construction of lesson plans and teaching, assessment methods and Pedagogical Political Project were indicated by participants as topics of interest for discussion in the community of practice, whose virtual format was appointed as preferential.

In this virtual community, it can bring (...) about the pedagogical issue or teaching method. (P7)
We brought as themes the lesson plan, teaching plan, political pedagogical project, methodologies and assessment methods. (P8)

The themes we put up: teaching methodologies, primarily active ones, construction of the lesson plan (...), we don't always bave the notion of a lesson plan. (P12)

\section{Agreement of Collective Commitments for the Teaching Community of Practice}

Participants agreed on some collective commitments that they considered essential for the enrichment of knowledge and accountability of all those involved in the teaching community of practice. They mentioned the need for engagement in actions, search for personal qualification, commitment to sharing information and encouraging participation, rigor to comply with the established times for meetings and mutual help.

In commitments, we put engagement in actions (...). As well as personal qualification, a specialization, master's, doctorate. This enriches me and ends up enriching the group when this knowledge is exchanged. (P8)

Commitments (...), sharing knowledge through the group, encouraging group participation and group meeting times. (P12)

Having commitment, accountability (...) sharing information. (...) mutual help. Having accountability, a commitment also in relation to the virtual group. (P13)

\section{DISCUSSION}

Teacher training was perceived by participants as a necessity, in the understanding that a bachelor's degree prepares to work in specific areas of knowledge and the degree to work in the classroom. Associated with this perception, it is relevant to highlight the small number of graduates, only $14 \%$ (2) of the total participants, as well as the fact that only a minority, $42.8 \%$ (6), have a graduate degree focused on teaching.

In fact, bachelor's education, with emphasis here on nursing, has a training path focused on care and management activities so that little (or nothing) is said about the possibility of teaching as a field of work ${ }^{(15)}$. Furthermore, it is known that the offer of a license for teaching in nursing is shy in the scenario of national higher education and that the search for graduate courses is closely related to the acquisition of knowledge in the area of professional practice ${ }^{(16,17)}$. Thus, there is an increasingly specialized professorship, far from the other basic knowledge of teaching.

The theoretical construct knowledge base for teaching indicates that teaching is a profession and, therefore, requires training, whose base structure comprises at least seven categories of knowledge, mentioned above ${ }^{(2,18)}$. It is evident that the full mastery of the specificity of a given area does not sufficiently enable the professor to teach.

The professor, by understanding what permeates and demands the teaching-learning process, can seek ways to promote their qualification, in order to contribute, more effectively, to learning.

However, despite realizing the need for training for teaching, the participants found it difficult to work and study at the same 
time, due to lack of time and rush of life. Certainly, an overloaded and troubled routine makes it difficult to reconcile work and study. For most nurses, this arrangement is even more painful due to an intense weekly workday, characterized, in general, by multi-employment ${ }^{(19,20)}$. As a result, there is a dizzying and crowded daily reality, making it difficult to reconcile another activity with work, even though this is as essential as professor education.

Furthermore, it is common for nurses not to recognize themselves as education professionals, an aspect that further hinders their access to pathways for teaching qualification ${ }^{(21)}$. Therefore, there is a performance of professors, even experienced by the long time of teaching, based exclusively on the theoretical-practical expertise of their area of knowledge.

The professionalization of teaching is resumed, since teaching is a complex activity that requires not only the depth of understanding of the subject taught, but also the expansion of the horizons of knowledge ${ }^{(2)}$.

Given the perception of the need for teacher training in conflict with the realization of the difficulty of working and studying at the same time, the recognition of the feasibility of forming in a group is highlighted, given the opportunity for learning in favor of qualification for teaching. The possibility of being in the community, understood here as a more informal space for permanent training, provides opportunities for sharing experiences and joint learning.

The interaction between professors, in particular, can provoke a look and reflection on their own trajectory of professor education and performance and on the trajectory and performance of the other as well as collective reflection with discussion and connection of experiences ${ }^{(1)}$. This (self)knowledge and (self)reflection of the experience of becoming and acting as a professor favors a critical awareness of reality, to the point of bringing about changes in the search for an expert professor's knowledge/doing ${ }^{(22)}$. Therefore, the relationship established collectively between these professionals is beneficial and configures as a powerful way for professor improvement.

Also, the approximation and exchange of experiences and practices in the teaching-learning process among professors make it possible to plan joint actions and interrelationship of subjects and contents that would probably be conducted in isolation ${ }^{(23)}$. This, in addition to generating the development of practice and knowledge of professors, positively reverberates in student learning and training.

In this perspective, there is the possibility of developing teaching community of practice, whose proposal was accepted by the participants, as they glimpsed the potential of permanent education to improve the knowledge necessary for teaching. As main actors of their learning and considering space-time flexibility, as they prefer a virtual format, they realized the possibility of expanding knowledge and skills with a view to teaching professionalism, such as Oliveira ${ }^{(24)}$.

Learning in community of practice takes place through the continuous interaction between people, who deepen their knowledge in a certain area by sharing concerns, problems and issues ${ }^{(9)}$. Therefore, community of practice sees learning as a fundamentally social phenomenon; therefore, knowing and learning is a matter of participating and interacting.
It is worth emphasizing that permanent training, formal or informal, is a necessity for the professor, as it allows for continuous updating and learning, aspects required by the complexity of their work, especially in a world of constant change ${ }^{(1,10)}$. It is also necessary, when considering the instrumentality required for teaching performance, given the requirements and specificities for teaching. Professors, therefore, need to be permanently in the training process to meet the demands and responsibilities arising from teaching.

Insofar as this continuous training process takes place in an environment of collaboration and social exchange, taking as an example a teaching community of practice, it is possible to have individual and collective reflexive movements, aiming at the elaboration of joint projects to solve problems, even the teaching practice itself ${ }^{(24-26)}$. In this way, professors' continuous professional learning and development can be made possible and fostered in the context of community of practice.

Therefore, a teaching community of practice "works as a group of professors who exchange, reflect and learn from each other, taking as raw material reports about their practices"(10). Thus, training for teaching can take place in these spaces of exchange and interaction, where professors, by sharing their difficulties and successes, anxieties and hopes, learn from each other towards facing the challenges experienced in teaching and with a focus on professionalizing teaching. Furthermore, referential knowledge for teaching practice and new meanings about teaching can be built on significant experiences and their exchanges among professors ${ }^{(23,27)}$.

Based on the understanding that in the community of practice there is a set of problems or central themes that are of interest to all members, the study participants, based on their reality and performance in the classroom, suggested some themes for discussion in the community, whose didactic-pedagogical character was remarkable. The pedagogical knowledge of those who have a bachelor's degree is shallow and deficient ${ }^{(21)}$ so that the need to expand this knowledge, categorically manifested in this study, assumes a strategic and irreplaceable place in the exercise of teaching.

Participants' manifestation around didactic-pedagogical improvement, such as teaching methods, lesson plan and assessment, endorsed the relevance of knowledge base for teaching ${ }^{(2)}$, in particular Pedagogical Content Knowledge, which emphasizes the ability to relate content to the most appropriate method, also considering Student Knowledge, Curriculum Knowledge and General Pedagogical Knowledge.

The reflections they made, identifying either a proximity or a distancing from the knowledge base for teaching framework ${ }^{(2)}$, was one of the reasons why it aroused great interest in its deepening.

It is worth noting that there is a need for mutual commitment between members so that the discussion of topics, the exchange of experiences and learning through the community of practice effectively take place ${ }^{(9)}$. This commitment is what makes a community of practice a community, being a source of coherence and resting on individual accountability to the collective $e^{(9,28)}$.

As commitments, engagement in actions, seeking personal qualification, sharing information, encouraging each other's 
participation and paying attention to the established times for meetings and mutual help were agreed. The agreement of commitments helps in the relationship between members and keeps them connected ${ }^{(9)}$, which will make the Teaching community of practice more solid and successful. It is interesting to point out that other commitments can be added later, throughout the community's practice, and there may be more committed members in relation to others ${ }^{(9)}$. One way or another, these (re)arrangements happen (and are necessary) in order to contextualize and keep the community of practice productive.

In addition to mutual commitment, there are also two inherent and indispensable properties of community of practice such as joint venture and shared repertoire ${ }^{(9)}$. This includes words, instruments, ways of doing things, symbols, etc., that the community produces and adopts in the course of its existence. The former, in turn, is related to the capacity for collective bargaining that reflects mutual commitment. Thus, all these elements enable the sharing of meanings and knowledge.

The teaching community of practice, as a possibility for permanent teacher training, provides opportunities for socialization of daily difficulties of teaching and exposes the gaps in knowledge regarding this work. It also enables the sharing of successful experiences and the exchange of experiences, in the sense of internalizing and recreating the knowledge that is cogent to teaching.

The development of the teaching community of practice in focus has an expressive potential, considering that one of the participants was the pedagogical coordinator of the school unit. Thus, there is a real openness and interest by the school in qualifying its professors, in the understanding that it is necessary to institutionally commit to a critical, ethical, humanized training of workers for nursing/health care in SUS.

Furthermore, the participation of a professor from outside the nursing area also allows for a glimpse of the possibility of involving professors from other areas and courses from ETSUS itself. This perspective of composition of the teaching community of practice brings out the wealth of experiences that can be shared and the powerful knowledge that can be collectively built for a qualified and transforming teaching performance.

\section{Study Limitations}

The study limitations are presented by the quantity of a school as research setting, by the heterogeneity of FG participants regarding the number and attendance per meeting and by the short time for monitoring the teaching community of practice development.

\section{ImPlicAtions for the AdVANCEMENT OF SCIENTIFIC Knowledge for Health and Nursing}

The study points to the indispensability of training for teaching in vocational nursing education for an expert teaching practice, with a consequent improvement in the quality of training of mid-level workers for nursing/health care, boosting the movement for teacher training policies for EPTNM. It also presents community of practice as a favorable space for professors' continuous learning and improvement.

\section{CONCLUSION}

The perception of the need for teacher training as well as the finding of the difficulty of reconciling work and study and the recognition of the opportunity to form a group by participants point out the possibility of developing a teaching community of practice from the perspective of permanent training for teaching in vocational nursing education. To develop it, some topics of interest were indicated for discussion and collective commitments were agreed to keep the community of practice active and productive.

The permanent training of professors is an important issue in the current setting of the teaching-learning process, as their training and performance are related to quality of education. This agenda gains even more emphasis when considering vocational nursing education, as most nurses start teaching without specific preparation and the technician's work occupies a relevant place in health care.

It is therefore urgent to discuss and design ways of teacher training for professors of vocational nursing education so that they are a critical stimulus for their teaching practices and provide opportunities for a continuous training path. In this way, it will be possible to strengthen the differentiated training of health professionals aware of their social commitment, with quality of care and SUS.

In this context, the teaching community of practice presents itself as a collective mode of learning for professors, as it allows the development of fundamental knowledge to their educational practice through the socialization of practical experiences and knowledge among peers. Each community of practice member can collaborate with precious elements in the search for qualification for teaching, cooperating for the personal and professional improvement of everyone involved.

By functioning as a group of vocational nursing professors who learn from each other through interaction and mutual commitment, the teaching community of practice can be characterized as a powerful way of permanent education for teaching. It is thus configured as a viable investment and a possible reality for teaching qualification that is so essential for the quality of education and excellence in health/nursing training.

\section{RESUMO}

Objetivo: Identificar possibilidades para o desenvolvimento de Comunidade de Prática docente como estratégia de formação permanente para a docência na educação técnica em enfermagem. Método: Pesquisa qualitativa do tipo pesquisa-ação, realizada com professores do curso técnico em enfermagem e coordenação pedagógica de uma Escola Técnica do Sistema Único de Saúde do Ceará. Os dados foram coletados por grupos focais e submetidos à análise de conteúdo de Bardin, com suporte do Qualitative Data Analysis Software. Resultados: Possibilidades para o desenvolvimento de comunidade de prática docente foram identificadas mediante a percepção da necessidade de formação docente, dificuldade de conciliar trabalho e estudo e viabilidade de promover esta formação em grupo. Conclusão: A comunidade de prática docente, além de ser uma estratégia viável para a formação docente em enfermagem, é premente, pois a formação de trabalhadores de nível médio é determinante para a qualidade do cuidado e consolidação do Sistema Único de Saúde. 
DESCRITORES

Docentes de Enfermagem; Capacitação de Professores; Docentes; Educação Técnica em Enfermagem; Enfermagem; Sistema Único de Saúde.

\section{RESUMEN}

Objetivo: Identificar posibilidades para el desarrollo de una comunidad de práctica docente como estrategia de formación permanente para la docencia en educación técnica en enfermería. Método: Investigación cualitativa del tipo investigación-acción, realizada con profesores del curso técnico en enfermería y coordinación pedagógica de una Escuela Técnica del Sistema Único de Salud de Ceará. Los datos fueron recopilados por grupos focales y enviados al análisis de contenido de Bardin, con el apoyo del software de análisis de datos cualitativos. Resultados: Se identificaron posibilidades para el desarrollo de una comunidad de práctica docente a través de la percepción de la necesidad de formación docente, la dificultad para conciliar trabajo y estudio, y la viabilidad de promover esta formación en grupos. Conclusión: La comunidad de práctica docente, además de ser una estrategia viable para la formación del profesorado de enfermería, es urgente, pues la formación de los trabajadores del nivel secundario es fundamental para la calidad de la atención y la consolidación del Sistema Unico de Salud.

\section{DESCRIPTORES}

Docentes de Enfermaría; Formación del Profesorado; Docentes; Graduación en Auxiliar de Enfermería; Enfermaría; Sistema Único de Salud.

\section{REFERENCES}

1. Souza APG, Anunciato RMM. Aprendizagens da docência em uma comunidade de aprendizagem online: contribuições da ReAD. Revista Brasileira de Pesquisa (Auto)Biográfica. 2019;4(12):1090-109. DOI: http://dx.doi.org/10.31892/rbpab2525-426x.2019.v4.n12.p1090-1109.

2. Shulman LS. Conhecimento e ensino: fundamentos para a nova reforma. Cadernos CENPEC. 2014;4(2):196-229. DOI: http://dx.doi.org/10.18676/ cadernoscenpec.v4i2.293

3. Granvile NC, Corrêa AK. Saberes dos professores da educação profissional técnica de nível médio em enfermagem. Revista Cocar. 2018 [cited 2020 Jul 18];12(23):408-38. Available from: https://periodicos.uepa.br/index.php/cocar/article/view/1734.

4. Hott MCM, Reinaldo AMS. Qualificação pedagógica de enfermeiros docentes em cursos profissionalizantes. Revista Brasileira da Educação Profissional e Tecnológica. 2018;2(15):1-14. DOI: https://doi.org/10.15628/rbept.2018.6455.

5. Ribeiro-Barbosa JC, Silva GT, Amestoy SC, Silva CCR, Silva RMO, Backes VMS. Technical schools of the Unified Health System: an analysis of nursing education. Rev Esc Enferm USP. 2020;54:e03580. DOI: https://doi.org/10.1590/S1980-220X2018052503580.

6. Tafner DPOV, Reibnitz KS, Lazzari DD. Implementation of the integrality principle in technical nursing courses at schools in the SUS network. Texto \& contexto enfermagem. 2016;25(4):e3470015. DOI: https://doi.org/10.1590/0104-07072016003470015.

7. Backes VMS, Menegaz JC, Miranda FAC, Santos LMC, Cunha AP, Patrício SS. Lee Shulman: contributions to research on teacher training. Texto \& contexto enfermagem. 2017;26(4):e1080017. DOI: https://doi.org/10.1590/0104-07072017001080017.

8. Corrêa AK, Sordi MRL. The secondary technical-professional education in the Unified Health System and the teacher training policy. Texto \& contexto enfermagem. 2018;27(1):e2100016. DOI: https://doi.org/10.1590/0104-07072018002100016.

9. Wenger E. Communities of practice: learning, meaning, and identity. Buenos Aires: Paidós; 2011.

10. Imbernón F, Shigunov Neto A, Silva AC. Reflexões sobre o conhecimento na formação de professores em comunidade de prática. Revista IberoAmericana de Educação. 2020;82(1):161-72. DOI: https://doi.org/10.35362/rie8213663.

11. Thiollent M. Metodologia da pesquisa-ação. 18ª . São Paulo: Cortez; 2011.

12. Ministério da Saúde: RET-SUS [Internet]. 2020. [cited 2020 Aug 19]. Available from: https://antigo.saude.gov.br/trabalho-educacao-e-qualificacao/ gestao-da-educacao/formacao-tecnica/rede-de-escolas-tecnicas-do-sus-ret-sus/escolas-tecnicas-e-centros-formadores.

13. Kinalski DDF, Paula CC, Padoin SMM, Neves ET, Kleinubing RE, Cortes LF. Focus group on qualitative research: experience report. Rev Bras Enferm. 2017;70(2):443-8. DOI: https://doi.org/10.1590/0034-7167-2016-0091.

14. Bardin L. Análise de conteúdo. São Paulo: Edições 70; 2016.

15. Sgarbi AKG, Missio L, Renovato RD, Hortelan MPSM. Enfermeiro docente no ensino técnico em enfermagem. Laplage em Revista. 2018;4(1):25473. DOI: http://doi.org/10.24115/s2446-6220201841423p.254-273.

16. Corrêa AK, Prebill GM, Ruiz JC, Souza MCBM, Santos RA. First-year student profile in the "bachelor's degree with a teaching credential in nursing" program at a brazilian public university. Educação em Revista. 2018;34:e185913. DOI: https://doi.org/10.1590/0102-4698185913.

17. Sordi MRL. Docência no ensino superior: interpelando os sentidos e desafios dos espaços institucionais de formação. Educação em Revista. 2019;35(75):135-54. DOI: https://doi.org/10.1590/0104-4060.67031.

18. Souza DM, Backes VMS, Lazzari DD, Santos LMC, Martini JG. Conhecimento Pedagógico de Conteúdo de docentes de enfermagem novatos na educação técnica de nível médio. Rev Bras Enferm. 2020;73(5):e20180976. DOI: https://doi.org/10.1590/0034-7167-2018-0976.

19. Machado MH, Koster I, Filho WA, Wermelinger MCMW, Freire NP, Pereira EJ. Labor market and regulatory processes - nursing in Brazil. Cien Saude Colet. 2020;25(1):101-12. DOI: https://doi.org/10.1590/1413-81232020251.27552019.

20. Machado $\mathrm{MH}$, Oliveira E, Lemos W, Lacerda WF, Filho WA, Wermelinger $M$, et al. Mercado de trabalho da enfermagem: aspectos gerais. Enfermagem em Foco [Internet]. 2016 [cited 2020 Jul 18];7(Esp):35-62. Available from: http://revista.cofen.gov.br/index.php/enfermagem/article/ view/691/301

21. Souza DM, Backes VMS, Lazzari DD, Martini JG. Pedagogical preparation of nursing professors for professional secondary technical education. Rev Bras Enferm. 2018;71(5):2432-9. DOI: https://doi.org/10.1590/0034-7167-2017-0289.

22. Canever BP, Prado ML, Gomes DC, Backes VMS, Jesus BH. Self-knowledge of health teachers: a qualitative exploratory study. Nurse Educ Today. 2018;65(2018):54-9. DOI: https://doi.org/10.1016/j.nedt.2018.02.035.

23. Freire VCC, Miranda ARA. Uma perspectiva autorreflexiva sobre experiências formativas docentes de dois professores iniciantes no ensino superior. Práticas Educativas, Memórias e Oralidades. 2019;1(2):1-18. DOI: https://doi.org/10.47149/pemo.v1i2.3511. 
24. Oliveira MLC. Desenvolvimento de comunidade de prática docente virtual: possibilidade de formação do enfermeiro docente novato [Thesis]. Florianópolis: Universidade Federal de Santa Catarina; 2018.

25. Imbernón F. Formação docente e profissional: formar-se para a mudança e a incerteza. 9a. São Paulo: Cortez; 2011.

26. Underwood J, Joshevka M. A proposed typology of knowledge sharing within communities of teachers: a comparative case study focusing on England and Macedonia. IAFOR Journal of Education [Internet]. 2019 [cited 2021 jul 14];7(1):113-28. Available from: https:/files.eric.ed.gov/ fulltext/EJ1217953.pdf.

27. Menegaz JC, Backes VMS, Moya JLM. Communities of practice: influences on pedagogical reasoning and action of nursing professors. Invest Educ Enferm. 2018;36(2):e02. DOI: https://doi.org/10.17533/udea.iee.v36n2e02.

28. Menegaz JC, Zamprogna KM, Backes VMS. Formação docente de ensino superior em diferentes contextos educacionais: reconhecimento para a construção de comunidades de prática. In: Backes VMS, Menegaz JC, Moya JLM, organizadores. Formação Docente na Saúde e Enfermagem. Porto Alegre: Moriá; 2019. p. 119-36.

\section{Financial Support}

This work was carried out with the support of the Coordination for the Improvement of Higher Education Personnel - Brazil (CAPES - Coordenação de Aperfeiçoamento de Pessoal de Nível Superior) - Financing Code 001.

Brazilian National Council for Scientific and Technological Development (Conselho Nacional de Desenvolvimento Científico e Tecnológico) - Research Productivity: Process 307977/2018-8 and Process 307517/2017-9. 